\title{
Expression of cyclin A in human leukemia cell line HL-60 following treatment with doxorubicin and etoposide: The potential involvement of cyclin $\mathrm{A}$ in apoptosis
}

\author{
AGNIESZKA ZURYN $^{1}$, ALINA GRZANKA ${ }^{1}$, ALEKSANDRA STEPIEN ${ }^{1}$, \\ DARIUSZ GRZANKA ${ }^{2}$, ROBERT DEBSKI $^{3}$ and DARIUSZ SMOLINSKI ${ }^{4}$
}

\begin{abstract}
${ }^{1}$ Department of Histology and Embryology, Nicolaus Copernicus University, Collegium Medicum, Karlowicza 24, 85-092
Bydgoszcz; ${ }^{2}$ Department of Clinical Pathomorphology, ${ }^{3}$ Department and Clinic of Pediatric, Hematology and Oncology, Nicolaus Copernicus University, Collegium Medicum, Sklodowskiej-Curie 9, 85-094 Bydgoszcz; ${ }^{4}$ Department of Cell Biology, Institute of General and Molecular Biology, Nicolaus Copernicus University, Gagarina 9, 87-100 Torun, Poland
\end{abstract}

Received October 10, 2006; Accepted January 24, 2007

\begin{abstract}
We investigated expression of cyclin A in HL-60 cells after induction of apoptosis with doxorubicin and etoposide. Following apoptotic trigger, both cells arrested in G2/M phase of the cell cycle and changes in morphology were noticed. Moreover, compared to control, the number of cells with cyclin A expression was changed and translocation of this protein from the nucleus to the cytoplasm was observed. The decrease in the number of cells with cyclin A expression, followed by the increase, and cyclin A distribution throughout the cell, appeared to be dose-dependent. Cells treated with lower doses of doxorubicin and etoposide as well as the untreated cells were found to have cyclin A scattered mainly throughout the nucleus. However, immunogold labeling of cyclin A in both cell lines treated with 5- and $10-\mu \mathrm{M}$ doses of doxorubicin, and 20 and $200 \mu \mathrm{M}$ of etoposide was observed more often in the cytoplasm than in the nucleus. Cells with features of apoptosis with bodies resembling micro-nuclei labeled with gold particles for cyclin A were recognized. However, the small amount of giant cells was also seen. These results suggest that cyclin A expression is linked to cell death pathways.
\end{abstract}

\section{Introduction}

Cyclin A is one of the major cell cycle regulatory proteins (1). The association with its catalytic partner, kinase (Cdk, cyclin-dependent kinase), leads to the partial activation of the

Correspondence to: Dr Alina Grzanka, Department of Histology and Embryology, Nicolaus Copernicus University, Collegium Medicum, 24 Karlowicza St, 85-092 Bydgoszcz, Poland

E-mail: agrzanka@cm.umk.pl

Key words: cyclin A, HL-60, doxorubicin, etoposide, apoptosis kinase complex cyclin $\mathrm{A} / \mathrm{Cdk}$, followed by the phosphorylation events resulting in its full activation $(1,2)$. During the cell cycle, cyclin $\mathrm{A}$ is associated with Cdk2 or $\mathrm{Cdc} 2$ (cell division cycle 2), also known as Cdk1 (2). The cyclin A/Cdk2 complex activity is required for the regulation of $\mathrm{S}$ phase progression $(2,3)$ whereas cyclin $\mathrm{A} / \mathrm{Cdk} 1$ regulates $\mathrm{G} 2 / \mathrm{M}$ transition (2). It has been widely accepted that cyclin A plays a very important role during the cell cycle. Cyclin A is present, not associated with Cdks, in the complex bound to chromatin as well as, complexed with Cdk2 or Cdk1 in S and G2 phase, respectively (4). It has been suggested that cyclin A/Cdk2 controls DNA replication by regulating activity of some replication machinery components (3-5). Moreover, activation of the cyclin A/Cdk2 complex has been found to be required for centrosome duplication (6-8) and centriole separation (9).

Some studies revealed the existence of a relationship between the level of cyclin A (10) or cyclin-dependent kinase (11) expression and apoptosis, thus between the cell cycle and programmed cell death (PCD). It has been also implicated that there is a link between cyclin A subcellular localization and its cell functions $(11,12)$. It is well known that apoptosis characterized by membrane blebbing, nuclear fragmentation, depolymerization of the cytoskeleton and chromatin condensation, usually begins in the cytoplasm while DNA replication and mitosis are nuclear processes $(13,14)$. Hiromura et al indicated that $\mathrm{Cdk} 2$ translocation from the nucleus to the cytoplasm is connected with its role in apoptosis and hypothesized that cyclin $\mathrm{A} / \mathrm{Cdk} 2$ mediates both growth and death pathways (12). Furthermore, another report suggested that cyclin A may cause mitotic catastrophe (15), the process considered as the mode of non-apoptotic cell death (16).

The chemotherapeutic agents used in the present study, doxorubicin (DOX) and etoposide (VP-16), function as topoisomerase II inhibitors, thereby inhibiting DNA synthesis (17). The human promyelocytic leukemia cell line (HL-60) has been proven to be particularly susceptible to cytotoxic drugs (18). The reasons behind this are c-Myc overexpression which is known to promote tumorigenesis and apoptosis (19-21) as well as a deficiency of the tumor suppressor protein 
p53 (22-24). HL-60 cells express also oncoprotein Bcl-2, which is an important anti-apoptotic agent $(22,25)$.

In this report we show the relationship between cell death pathways and the cell cycle protein - cyclin A alternations in the HL-60 cell line.

\section{Materials and methods}

Cell culture. The human promyelocytic leukemia cell line HL-60 (ATCC CCL 240) used in this study, was routinely cultured in RPMI-1640 medium containing 10\% fetal calf serum and $20 \mu \mathrm{l}$ gentamycin in fully humidified atmosphere of $5 \% \mathrm{CO}_{2}$ at $37^{\circ} \mathrm{C}$. Cells were incubated with 3 different concentrations of doxorubicin (Sigma, St. Louis, MO, USA) $(0.5,5$ and $10 \mu \mathrm{M})$ and 4 concentrations of etoposide (Sigma) $(0.2,2,20$ and $200 \mu \mathrm{M})$ for $72 \mathrm{~h}$. Control cells were grown in identical conditions. Cell viability was assessed by the trypan blue dye exclusion method. The experiment was repeated 10 times.

Immunocytochemistry. Cells fixed in $4 \%$ paraformaldehyde were centrifuged at a low speed and transferred to microscope slides. Cyclin A was detected by the streptavidin-biotinperoxidase technique. Sections were treated with monoclonal antibody against cyclin A (Sigma) diluted 1:100 in phosphatebuffered saline for $1 \mathrm{~h}$. Then, they were incubated for $40 \mathrm{~min}$ with biotin-labeled secondary antibody and Dako LSAB Kit peroxidase. Subsequently, the sections were developed with diaminobenzidine for $5 \mathrm{~min}$ and counterstained with Meyer's hematoxylin. Control specimens were incubated with nonimmune antiserum (normal mouse serum, Dako, Glostrup, Denmark).

Immunofluorescence assay. Cells were fixed with $4 \%$ paraformaldehyde ( $\mathrm{pH} \mathrm{7.4)}$ ) for $15 \mathrm{~min}$, at $4^{\circ} \mathrm{C}$, washed twice with PBS and collected directly onto microscopical slides using a cytocentrifuge (Megafuge1, OR, Heraeus, Sepatech). Cells on slides were incubated in permeabilization solution $(0.1$ Triton X-100 in PBS) and blocked with 1\% BSA (Gibco). After permeabilization, cells were incubated with anti-cyclin A monoclonal antibody (Sigma) for $45 \mathrm{~min}$ at room temperature, washed three times with PBS and incubated with antimouse IgG TRITC conjugated antibody (Sigma) for $45 \mathrm{~min}$, at room temperature. After incubation, cells were washed with PBS and mounted in gelvatol (Monsanto, St. Louis, USA). Nuclear staining was performed with DAPI (Sigma). Both cyclin A and DNA staining was examined with an Eclipse E600 microscope (Nikon, Tokyo, Japan) and with a confocal microscope (inverted microscope, Nikon, Eclipse TE 300).

Electron microscopy. To visualize Cyclin A at the ultrastructural level, a post-embedding streptavidin-gold method was used. Cells were fixed in 4\% paraformaldehyde in PBS for $1 \mathrm{~h}$ at $4^{\circ} \mathrm{C}$, washed overnight with $\mathrm{PBS}$ at $4^{\circ} \mathrm{C}$, dehydrated in series of ethanol and embedded in LR White. Thin sections were collected on nickel grids. The grids were floated on a drop of non-immune rabbit serum (Dako) for $20 \mathrm{~min}$ and then transferred onto drops of mouse anti-human cyclin A antibody (Sigma) diluted 1:100. After incubation with primary antibody for $30 \mathrm{~min}$, thin sections on grids were rinsed in PBS

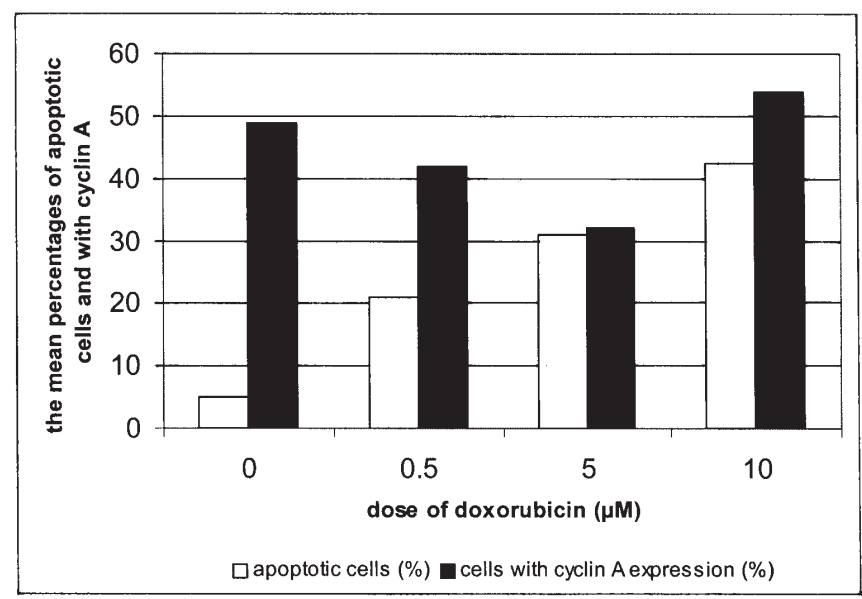

Figure 1. The percentages of apoptotic cells and with cyclin A expression in HL-60 cell line after treatment with doxorubicin.

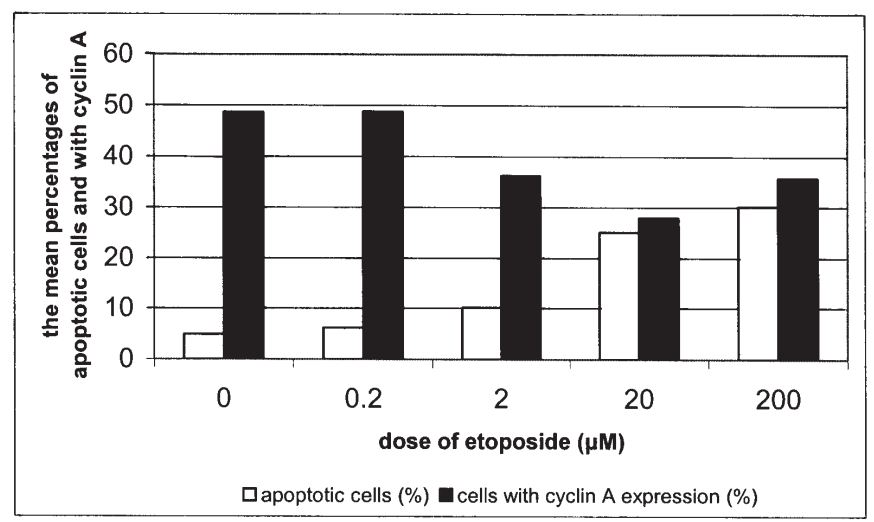

Figure 2. The percentages of apoptotic cells and with cyclin A expression in HL-60 cell line after treatment with etoposide.

and incubated with biotinylated rabbit anti-mouse antibody (Dako) diluted 1:100. Grids were then rinsed in PBS and transferred onto drops of solution containing $10 \mathrm{~nm}$ gold particles conjugated to streptavidin (Sigma), 1:20 dilution, and incubated for $30 \mathrm{~min}$. After this final incubation grids were washed with PBS and dried. All incubation steps were performed at room temperature. Control specimens were incubated with non-immune antiserum (normal mouse serum, Dako). The preparations were examined using a transmission electron microscope JEM 100 CX (JEOL, Tokyo, Japan) at $80 \mathrm{kV}$.

Flow cytometric assessment of cell cycle and apoptosis. For the cell cycle analysis cells were stained with hypotonic propidium iodide solution $(20 \mu \mathrm{g} / \mathrm{ml}$, DNA - Prep Kit) and 20000 events were analyzed with an Epis XL flow cytometer. Cell cycle phases were calculated by multicycle software (Phoenix Flow Systems, San Diego). Percentage of the cells in G1/0, S and $\mathrm{G} 2 / \mathrm{M}$ phase was expressed as mean \pm standard deviation.

Apoptosis was analyzed, using the Annexin V-FITC apoptosis detection kit (BD Pharmingen, San Diego, CA). This assay was performed according to the manufacturer's instructions. 
Table II. The effects of etoposide doses on cell viability.

\begin{tabular}{ccc}
\hline & \multicolumn{2}{c}{ HL-60 } \\
\cline { 2 - 3 } Dose $(\mu \mathrm{M})$ & Mean $(\%)$ & Standard variation \\
\hline 0.0 & 94.0 & 2.14 \\
0.2 & 90.2 & 3.09 \\
2.0 & 79.8 & 6.79 \\
20.0 & 76.1 & 7.77 \\
200.0 & 57.5 & 8.84 \\
\hline
\end{tabular}

Statistical analysis. The Shapiro-Wilk test was used to test data for normal distribution. Statistical significance of the data was determined by one-way analysis of variance (ANOVA) and Tukey's post hoc test. Results were considered significant at $\mathrm{P}<0.05$.

\section{Results}

To determine the number of HL-60 cells with cyclin A expression as well as the amount of apoptotic cells after treatment with DOX and VP-16, light (LM), electron (EM) and fluorescence confocal microscopy (FCM) as well as flow cytometry were used.

The changes in the number of the cells with cyclin A expression and the number of the apoptotic cells were found to be dependent on doxorubicin (DOX) and etoposide (VP-16) concentration. The effects of DOX and VP-16 on HL-60 cells resulting in the changes in both the percentage of the cells with cyclin A expression and with morphological features of apoptosis are shown in Figs. 1 and 2. We observed a clear decrease in expression of cyclin A in treated with VP-16 at doses of 2 and $20 \mu \mathrm{M}$ (Fig. 2) and DOX at 0.5 and $5 \mu \mathrm{M}$ (Fig. 1), and an increase in its expression at $200 \mu \mathrm{M}$ of VP-16
Table I. The effects of doxorubicin doses on cell viability.

\begin{tabular}{lcc}
\hline & \multicolumn{2}{c}{ HL-60 } \\
\cline { 2 - 3 } Dose $(\mu \mathrm{M})$ & Mean $(\%)$ & Standard variation \\
\hline 0.0 & 94.0 & 2.14 \\
0.5 & 86.1 & 4.31 \\
5.0 & 79.9 & 6.78 \\
10.0 & 64.0 & 5.70 \\
\hline
\end{tabular}

(Fig. 2) and DOX at $10 \mu \mathrm{M}$ (Fig. 1). It is important to note that at the doses of $200 \mu \mathrm{M}$ of VP-16 and $10 \mu \mathrm{M}$ of DOX the number of cells with cyclin A expression increased significantly and was parallel to the increase in the number of apoptotic cells (Figs. 1 and 2).

There was a statistically significant difference in the mean number of apoptotic cells after treatment with different doxorubicin and etoposide concentrations $(\mathrm{P}<0.01)$ except for the difference between $0.2 \mu \mathrm{M} \mathrm{VP}-16$ and control $(0.0 \mu \mathrm{M})$. There was also a significant difference in the mean number of the cells with cyclin A expression after treatment with different doses of both anticancer compounds, except for the difference between 0.5 and $10.0 \mu \mathrm{M}$ of DOX and control $(0.0 \mu \mathrm{M})$ as well as between $2.0 \mu \mathrm{M}$ and $200 \mu \mathrm{M}$ of VP-16, $0.2 \mu \mathrm{M}$ of VP-16 and control $(0.0 \mu \mathrm{M})$.

Tables I and II show the effects of DOX and VP-16 on cell viability. The inhibition of the cell viability that had been also demonstrated by flow cytometric analysis (Tables III and IV) was evident. Moreover, Tables III and IV show results confirming the above-mentioned observation of the positive correlation between cytostatic doses and the number of dead cells. Also, the morphological changes in the cells were found to be dependent on the dose of DOX and VP-16. A number of the cells treated with the highest DOX and VP-16

Table III. Flow cytometric analysis of viable, apoptotic and necrotic HL-60 cells after treatment with etoposide using Annexin V and propidium iodide staining.

\begin{tabular}{|c|c|c|c|c|c|c|c|c|c|c|}
\hline & \multicolumn{2}{|c|}{ Viable cells } & \multicolumn{2}{|c|}{ Necrotic cells } & \multicolumn{2}{|c|}{ Early apoptosis } & \multicolumn{2}{|c|}{ Late apoptosis } & \multicolumn{2}{|c|}{$\begin{array}{l}\text { Early and late } \\
\text { apoptosis }\end{array}$} \\
\hline & $(\%)$ & SD & $(\%)$ & SD & $(\%)$ & SD & $(\%)$ & SD & $(\%)$ & SD \\
\hline Control & 93.53 & 0.82 & 4.46 & 1.24 & 1.96 & 0.29 & 0.08 & 0.09 & 2.04 & 0.35 \\
\hline $\begin{array}{l}\text { Etoposide } \\
(0.2 \mu \mathrm{M})\end{array}$ & 94.23 & 1.18 & 3.55 & 0.67 & 2.13 & 0.79 & 0.10 & 0.09 & 2.23 & 0.73 \\
\hline $\begin{array}{l}\text { Etoposide } \\
(2 \mu \mathrm{M})\end{array}$ & 67.50 & 2.16 & 20.67 & 1.63 & 11.02 & 1.13 & 0.84 & 0.29 & 11.86 & 0.97 \\
\hline $\begin{array}{l}\text { Etoposide } \\
(20 \mu \mathrm{M})\end{array}$ & 30.33 & 5.97 & 11.94 & 2.89 & 55.43 & 6.48 & 2.24 & 1.89 & 57.68 & 7.93 \\
\hline $\begin{array}{l}\text { Etoposide } \\
(200 \mu \mathrm{M})\end{array}$ & 15.77 & 3.72 & 7.07 & 2.35 & 70.77 & 2.72 & 6.39 & 1.13 & 77.15 & 1.92 \\
\hline
\end{tabular}


Table IV. Flow cytometric analysis of viable, apoptotic and necrotic HL-60 cells after treatment with doxorubicin using Annexin $\mathrm{V}$ and propidium iodide staining.

\begin{tabular}{|c|c|c|c|c|c|c|c|c|c|c|}
\hline & \multicolumn{2}{|c|}{ Viable cells } & \multicolumn{2}{|c|}{ Necrotic cells } & \multicolumn{2}{|c|}{ Early apoptosis } & \multicolumn{2}{|c|}{ Late apoptosis } & \multicolumn{2}{|c|}{$\begin{array}{l}\text { Early and late } \\
\text { apoptosis }\end{array}$} \\
\hline & $(\%)$ & SD & $(\%)$ & SD & $(\%)$ & SD & $(\%)$ & SD & $(\%)$ & SD \\
\hline Control & 93.33 & 0.82 & 1.91 & 1.24 & 3.97 & 0.29 & 0.75 & 0.09 & 4.72 & 0.35 \\
\hline $\begin{array}{l}\text { Doxorubicin } \\
(0.5 \mu \mathrm{M})\end{array}$ & 81.40 & 1.18 & 3.20 & 0.67 & 12.93 & 0.79 & 2.42 & 0.09 & 15.35 & 0.73 \\
\hline $\begin{array}{l}\text { Doxorubicin } \\
(5 \mu \mathrm{M})\end{array}$ & 68.93 & 2.16 & 15.28 & 1.63 & 13.80 & 1.13 & 2.00 & 0.29 & 15.80 & 0.97 \\
\hline $\begin{array}{l}\text { Doxorubicin } \\
(10 \mu \mathrm{M})\end{array}$ & 49.10 & 5.97 & 21.06 & 2.89 & 25.73 & 6.48 & 4.06 & 1.89 & 29.76 & 7.93 \\
\hline
\end{tabular}

concentrations, especially those at $10 \mu \mathrm{M}$ of DOX, were bigger in size (Fig. 3b) compared with non-treated cells (Fig. 3a). Our immunocytochemical labeling of cyclin A showed its presence predominantly in the nucleus of nontreated cells (Fig. 3a) whereas in the cells treated with $10 \mu \mathrm{M}$ of DOX (Fig. 3b), and 20 and $200 \mu \mathrm{M}$ of VP-16 (Fig. 3c) cyclin A was present mainly in the cytoplasm. Confocal laser microscopy images showed a similar pattern (Fig. 3d). Cyclin A distribution, at the ultrastructural level using immunogold labeling, was examined in the cells treated with anticancer compounds as well as in the control cells. In the cells treated with lower doses of DOX and VP-16 and non-treated, cyclin A was scattered predominantly throughout the nucleus (Fig. 4a). Immunogold labeling of cyclin A in the cells treated with 5and $10-\mu \mathrm{M}$ doses of DOX, and 20 and $200 \mu \mathrm{M}$ of VP-16 was observed more often in the cytoplasm than in the nucleus (Fig. 4b). There were also cells with characteristic features of apoptosis with bodies resembling micro-nuclei labeled with gold particles for cyclin A (Fig. 4c). Cyclin A labeling was not found in the control cells incubated with non-immune serum (Fig. 4d).

The cell cycle analysis using flow cytometry demonstrated that DOX and VP-16 treatment induced the cell cycle arrest at $\mathrm{G} 2 / \mathrm{M}$ in a dose-dependent manner (Figs. 5 and 6). The highest percentage $(19.4 \%)$ of HL-60 cells at G2/M was observed at the dose of $200 \mu \mathrm{M}$ of VP-16 (Fig. 6). There was also an increase in the number of HL-60 cells arrested at G2/M phase after treatment with DOX at doses of 0.5 and $5 \mu \mathrm{M}$ (Fig. 5). A dose of $10 \mu \mathrm{M}$ of DOX caused a decrease in the number of HL-60 cells at G2/M phase.

\section{Discussion}

It has been shown that some of the cell cycle regulators are able to affect both division and death of the cell. These are, among others, Cdks, cyclins, c-Myc, p53 and Bcl-2 (21). Cyclin A is mainly known as the cell cycle protein $(1,3,26)$. There are several reports however, demonstrating its proapoptotic role $(10,11,27)$. Furthermore, there are reports considering this protein as a prognostic marker in cancer and a predictive factor for chemotherapy response (28-34). A high level of cyclin A expression has been proven to be associated with good prognosis in AML (acute myeloid leukemia) patients (31). On the contrary, patients with cyclin A-positive non-small-cell lung carcinomas (NSCLCs) had a worse outcome than those with cyclin A-negative carcinomas (34). Similarly, overexpression of cyclin A was found to be associated with reduced overall survival in colorectal cancer patients (28). Another study has suggested the role for cyclin A/Cdk2 in the induction of apoptosis in SK-HEP-1 (human hepatoma cell line) after treatment with G-Rh2 (ginsenoside Rh2) (35). Other evidence indicates that overexpression of the wild-type form of cyclin A or Cdc2, Cdk2, and Cdk3 may circumvent the anti-apoptotic activity of the Bcl-2 in human HeLa cells (36). The ability of cyclin A to induce programmed cell death was also determined in rat fibroblasts exposed to low serum (10).

All the above-mentioned studies provide clear evidence that there is a link between cyclin A expression and apoptosis. Our previous report demonstrated this relationship as well. We found that in K-562 the mean percentage of the cells expressing cyclin A increased together with the percentage of cells with morphological features of apoptosis (37). In the present study we used the HL-60 cell line and two anticancer compounds, doxorubicin (DOX) and etoposide (VP-16), to investigate whether the previously observed relationship would be confirmed. The results obtained from the present study demonstrate that the used chemotherapeuticals induce changes in the level of cyclin A expression in HL-60 cells in a dose-dependent manner. The number of apoptotic cells increased together with the increase of DOX and VP-16 concentrations. Conversely, under the same conditions, there was a decrease in the number of cells with cyclin A expression, except for the treatment using the highest concentrations of the drugs $(200 \mu \mathrm{M}$ of VP-16, $10 \mu \mathrm{M}$ of DOX), where the number of cells with cyclin A labeling increased. The concentration-dependent decrease and increase in the level of cyclin A expression is intriguing. We suggest that the observed changes represent a kind of 'threshold' in which cyclin A changes its function from proliferating into proapoptotic. 


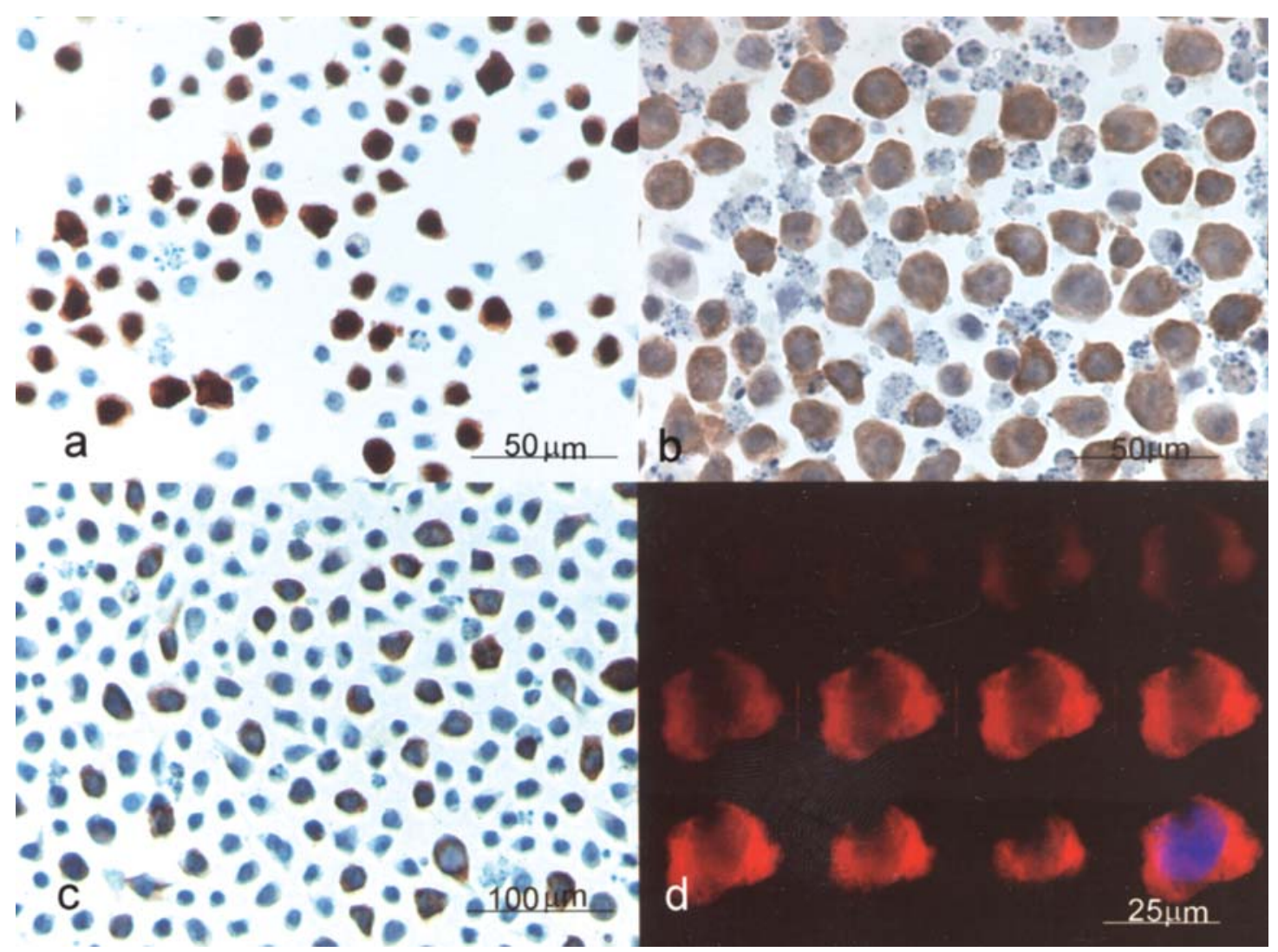

Figure 3. Non-treated HL-60 cells labeled with cyclin A (a). Cells treated with $10 \mu \mathrm{M}$ of DOX for $72 \mathrm{~h}$. Cyclin A labeling was observed throughout the cytoplasm. Apoptotic cells were observed (b). HL-60 cells treated with $200 \mu \mathrm{M}$ of VP-16 for $72 \mathrm{~h}$. Cells with cyclin A expression in the cytoplasm were recognized (c). Z-line construction through the HL-60 cell treated with $10 \mu \mathrm{M}$ of DOX for $72 \mathrm{~h}$. Strong cyclin A labeling throughout the cytoplasm was evident. Cyclin A labeling was not observed in the nucleus (d).

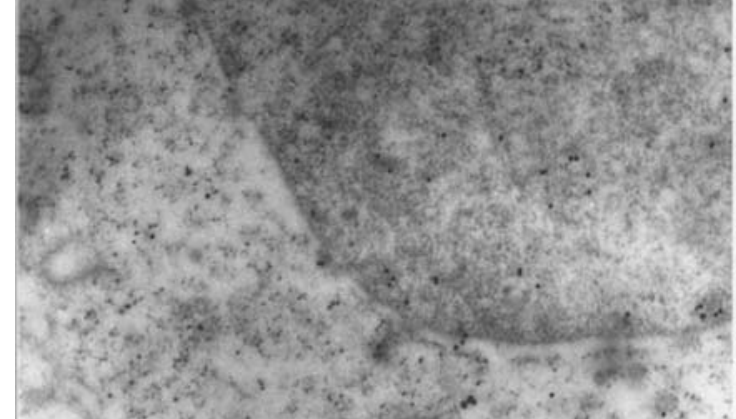

A

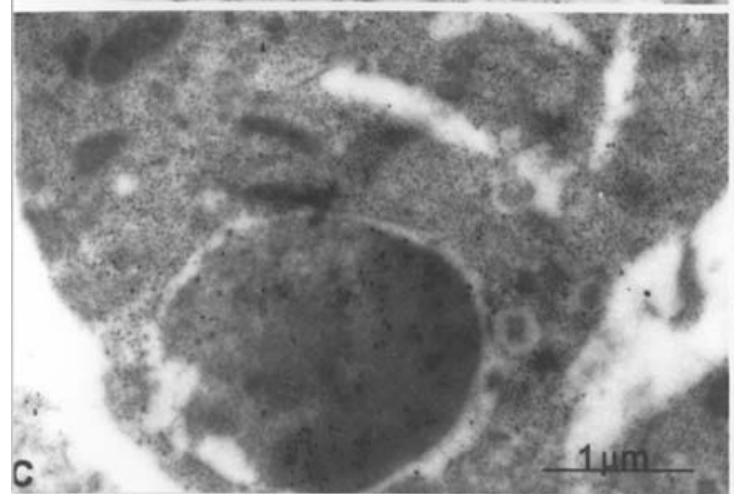

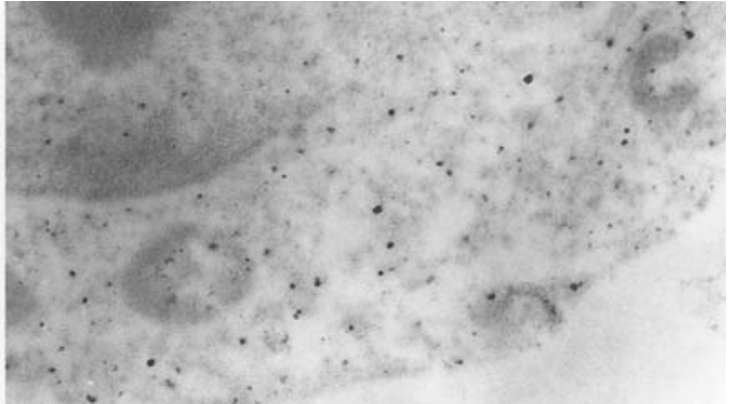

$1 \mu \mathrm{m}$

Figure 4. Electron microphotographs of HL-60 cells labeled with gold method. Non-treated control cells. The gold labeling for cyclin A was observed predominantly in the nucleus (a). Cells treated with $10 \mu \mathrm{M}$ of DOX for $72 \mathrm{~h}$. Immunogold labeling for cyclin A was present in the cytoplasm (b). The body labeled with gold particles for cyclin A in HL-60 cells treated with $200 \mu \mathrm{M}$ of VP-16 (c). Control HL-60 cells incubated with non-immune serum. Immunogold of cyclin A was not observed (d). 


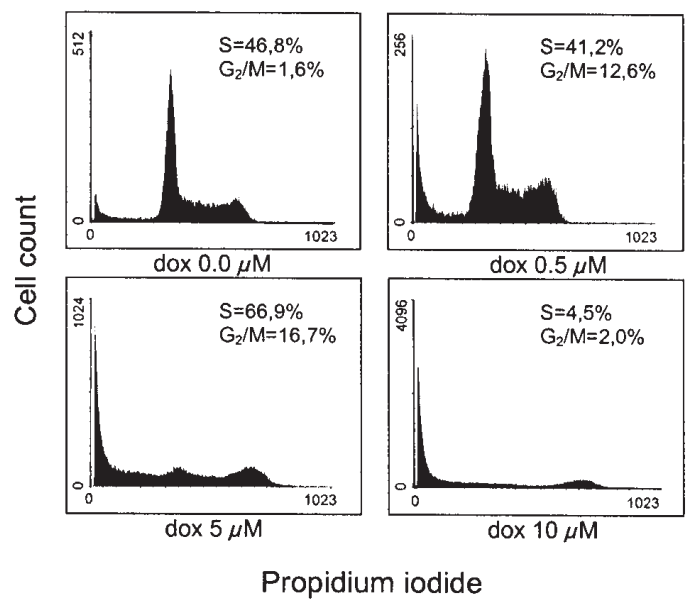

Figure 5. Cell cycle analysis of HL-60 cells after doxorubicin treatment.

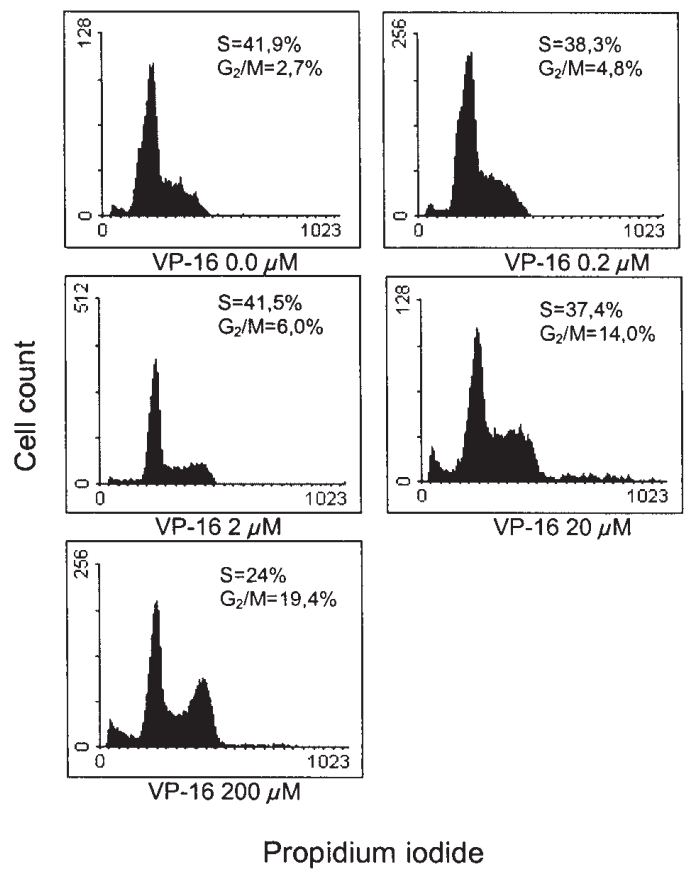

Figure 6. Cell cycle analysis of HL-60 cells after etoposide treatment.

It has been suggested that cyclin $\mathrm{A}$ is able to translocate from the nucleus to the cytoplasm, and thus interact with both nuclear and cytoplasmic substrates (38). Furthermore, there is growing evidence that subcellular localization of Cdks or cyclins may be connected with cell death pathways $(12,39)$. Cytoplasmic cyclin A localization was also found to have an impact on cell transformation (39). We noticed that in HL-60 cells after exposure to doses of 5 and $10 \mu \mathrm{M}$ of DOX and 20 and $200 \mu \mathrm{M}$ of VP-16, cyclin A translocated from the nucleus to the cytoplasm. A similar relationship was observed by Hiromura et al (12) who studied the role of subcellular localization of Cdk2 during apoptosis induced by UV irradiation in mouse mesangial cells. They found that cyclin $\mathrm{A} / \mathrm{Cdk} 2$ complexes were present predominantly throughout the cytoplasm following UV irradiation whereas, under these conditions, nuclear cyclin $\mathrm{A} / \mathrm{Cdk} 2$ activity decreased significantly. The association of cyclin $\mathrm{A} / \mathrm{Cdks}$ with programmed cell death has been also found by Ekberg et al, who demonstrated that although the subcellular localization of cyclin A was nuclear and cytoplasmic, both in the normal hematopoietic cells and leukemic blasts from AML patients, the latter characterized the higher level of cyclin A expression. A decline in the level of nuclear cyclin A following ATRA (all-trans retinoic acid) treatment was also observed (40).

Another noteworthy observation in our study was that a number of cells arrested in G2/M phase of the cell cycle in response to an apoptotic trigger. There are other studies demonstrating similar results $(32,41-43)$. The arrest of the cell cycle in G2/M was observed in the K-562 leukemic cell line after exposure to etoposide. This etoposide-induced event was found to impart resistance to programmed cell death and promote cell survival in K-562 cells (42). Similarly, in lymphoblastoid cell lines CEM and MOLT-4, cell cycle arrest at $\mathrm{G} 2 / \mathrm{M}$ following genotoxic agent etoposide was observed. This data showed that cells accumulated at G2/M underwent cell death or survived by re-entering mitosis (43). Furthermore, in HL-60, inhibition of cell proliferation and accumulation of the cells in G2/M followed by cell death after treatment with quercetin $(\mathrm{QU})$ or $\mathrm{QU}$ combined with doxorubicin were also demonstrated (44). Moreover, other reports show the positive correlation between the amount of cyclin A RNA and the cumulative percentage of cells in G2/M phase and, therefore, support the possibility to use cyclin $\mathrm{A}$ as a novel index to clinical oncology (32).

Based on evidence for the translocation of cyclin A from the nucleus to the cytoplasm occurring almost simultaneously with its expression increase after exposure to an apoptotic trigger, we conclude that cyclin A is involved in apoptotic cell death pathways in a dose-dependent manner. We are not able however to explain this phenomenon and link cyclin A into molecular pathway of cell death at this stage of our study.

\section{Acknowledgements}

The study was supported by the Nicolaus Copernicus University, Collegium Medicum (grant BW 27/2006).

\section{References}

1. McGowan CH: Regulation of the eukaryotic cell cycle. Prog Cell Cycle Res 5: 1-4, 2003.

2. Garrett MD: Cell cycle control and cancer. Curr Sci 8: 515-522, 2001.

3. Woo RA and Poon RY: Cyclin-dependent kinases and S phase control in mammalian cells. Cell Cycle 2: 316-324, 2003.

4. Frouin I, Montecucco A, Biamonti G, Hubscher U, Spadari S and Maga G: Cell cycle-dependent dynamic association of cyclin/ Cdk complexes with human DNA replication proteins. EMBO J 21: 2485-2495, 2002.

5. Sobczak-Thepot J, Harper F, Florentin Y, Zindy F, Brechot C and Puvion E: Localization of cyclin A at the sites of cellular DNA replication. Exp Cell Res 206: 43-48, 1993.

6. Tsou MF and Stearns T: Controlling centrosome number: licenses and blocks. Curr Opin Cell Biol 18: 74-78, 2006.

7. D'Assoro AB, Busby R, Suino K, et al: Genotoxic stress leads to centrosome amplification in breast cancer cell lines that have an inactive G1/S cell cycle checkpoint. Oncogene 23: 4068-4075, 2004.

8. Meraldi P, Lukas J, Fry AM, Bartek J and Nigg EA: Centrosome duplication in mammalian somatic cells requires E2F and Cdk2cyclin A. Nat Cell Biol 1: 88-93, 1999. 
9. Lacey KR, Jackson PK and Stearns T: Cyclin-dependent kinase control of centrosome duplication. Proc Natl Acad Sci USA 96: 2817-2822, 1999.

10. Hoang AT, Cohen KJ, Barrett JF, Bergstrom DA and Dang CV: Participation of cyclin A in Myc-induced apoptosis. Proc Nat Acad Sci USA 91: 6875-6879, 1994.

11. Borgne A and Golsteyn RM: The role of cyclin-dependent kinases in apoptosis. Prog Cell Cycle Res 5: 453-459, 2003.

12. Hiromura K, Pippin JW, Blonski MJ, Roberts JM and Shankland SJ: The subcellular localization of cyclin-dependent kinase 2 determines the fate of mesangial cells: role in apoptosis and proliferation. Oncogene 21: 1750-1758, 2002.

13. Green DR and Reed JC: Mitochondria and apoptosis: Science 281: 1309-1312, 1998

14. Minn AJ, Swain RE, Ma A and Thompson CB: Recent progress on the regulation of apoptosis by Bcl-2 family members. Adv Immunol 70: 245-279, 1998

15. Heald R, McLoughlin M and McKeon F: Human wee1 maintains mitotic timing by protecting the nucleus from cytoplasmically activated Cdc2 kinase. Cell 74: 463-474, 1993.

16. Ricci MS and Zong WX: Chemotherapeutic approaches for targeting cell death pathways. Oncologist 11: 342-357, 2006.

17. Hengstler JG, Heimerdinger CK, Schiffer IB, et al: Dietary topoisomerase II-poisons: contribution of soy products to infant leukemia. EXCLI J 1: 8-14, 2002

18. Kaufmann SH: Induction of endonucleolytic DNA cleavage in human acute myelogenous leukemia cells by etoposide camptothecin, and other cytotoxic anticancer drugs: a cautionary note Cancer Res 49: 5870-5878, 1989.

19. Evan GI, Wyllie AH, Gilbert CS, et al: Induction of apoptosis in fibroblasts by c-myc protein. Cell 69: 119-128, 1992.

20. Nass SJ and Dickson RB: Defining a role for c-Myc in breast tumorigenesis. Breast Cancer Res Treat 44: 1-22, 1997.

21. Vermeulen K, Berneman ZN and van Bockstaele DR: Cell cycle and apoptosis. Cell Prolif 36: 165-175, 2003

22. Evan GI and Vousden KH: Proliferation, cell cycle and apoptosis in cancer. Nature 411: 342-348, 2001

23. Fukasawa K, Choi T, Kuriyama R, Rulong S and van de Woude GF: Abnormal centrosome amplification in the absence of p53. Science 271: 1744-1747, 1996.

24. Wolf D and Rotter V: Major deletions in the gene encoding the p53 tumor antigen cause lack of p53 expression in HL-60 cells. Proc Natl Acad Sci USA 82: 790-794, 1985.

25. Delia D, Aiello A, Soligo D, et al: Bcl-2 proto-oncogene expression in normal and neoplastic human myeloid cells. Blood 79: 1291-1298, 1992.

26. Walker DH and Maller JL: Role for cyclin A in the dependence of mitosis on completion of DNA replication. Nature 354: 314-317, 1991

27. Harvey KJ, Blomquist JF and Ucker DS: Commitment and effector phases of the physiological cell death pathway elucidated with respect to $\mathrm{Bcl}-2$ caspase, and cyclin-dependent kinase activities. Mol Cell Biol 18: 2912-2922, 1998.

28. Bahnassy AA, Zekri AR, El-Houssini S, El-Shehaby AM, Mahmoud MR, Abdallah S and El-Serafi M: Cyclin A and cyclin D1 as significant prognostic markers in colorectal cancer patients. BMC Gastroenterol 4: 22, 2004
29. Huuhtanen RL, Blomqvist CP, Bohling TO, et al: Expression of cyclin A in soft tissue sarcomas correlates with tumor aggressiveness. Cancer Res 59: 2885-2890, 1999.

30. Kawashima R, Haisa M, Kimura M, et al: Cyclin A correlates with the sensitivity of human cancer cells to cytotoxic effects of 5-FU. Int J Oncol 24: 273-278, 2004.

31. Nakamaki T, Hamano Y, Hisatake J, et al: Elevated levels of cyclin A1 and A (A2) mRNA in acute myeloid leukaemia are associated with increased survival. Br J Haematol 123: 72-80, 2003.

32. Paterlini P, Suberville AM, Zindy F, et al: Cyclin A expression in human hematological malignancies: a new marker of cell proliferation. Cancer Res 53: 235-238, 1993.

33. Shiohara S, Shiozawa T, Miyamoto T, et al: Expression of cyclins, p53 and Ki-67 in cervical squamous cell carcinomas: overexpression of cyclin A is a poor prognostic factor in stage Ib and II disease. Virchows Arch 446: 626-633, 2005.

34. Volm M, Koomagi R, Mattern J and Stammler G: Cyclin A is associated with an unfavourable outcome in patients with nonsmall-cell lung carcinomas. Br J Cancer 75: 1774-1778, 1997.

35. Jin YH, Yoo KJ, Lee YH and Lee SK: Caspase 3-mediated cleavage of p21WAF1/CIP1 associated with the cyclin A-cyclindependent kinase 2 complex is a prerequisite for apoptosis in SK-HEP-1 cells. J Biol Chem 275: 30256-30263, 2000.

36. Meikrantz W and Schlegel R: Suppression of apoptosis by dominant negative mutants of cyclin-dependent protein kinases. J Biol Chem 271: 10205-10209, 1996.

37. Grzanka A, Zuryn A, Styczynski J, Grzanka AA and Wisniewska $\mathrm{H}$ : The effect of doxorubicin on the expression of cyclin A in K-562 leukemia cell line. Neoplasma 52: 489-493, 2005.

38. Jackman M, Kubota Y, Den Elzen N, Hagting A and Pines J: Cyclin A- and cyclin E-Cdk complexes shuttle between the nucleus and the cytoplasm. Mol Biol Cell 13: 1030-1045, 2002.

39. Faivre J, Frank-Vaillant M, Poulhe R, et al: Centrosome overduplication, increased ploidy and transformation in cells expressing endoplasmic reticulum-associated cyclin A2. Oncogene 21: 1493-1500, 2002.

40. Ekberg J, Landberg G, Holm C, Richter J, Wolgemuth DJ and Persson JL: Regulation of the cyclin A1 protein is associated with its differential subcellular localization in hematopoetic and leukemic cells. Oncogene 23: 9082-9089, 2004.

41. Blagosklonny MV: Sequential activation and inactivation of G2 checkpoints for selective killing of p53-deficient cells by microtubule-active drugs. Oncogene 21: 6249-6254, 2002.

42. Higginbottom K, Cummings M, Newland AC and Allen PD: Etoposide-mediated deregulation of the $\mathrm{G}_{2} \mathrm{M}$ checkpoint in myeloid leukaemic cell lines results in loss of cell survival. Br J Haematol 119: 956-964, 2002.

43. Sleiman RJ and Stewart BW: Early caspase activation in leukemic cells subject to etoposide-induced $\mathrm{G}_{2}-\mathrm{M}$ arrest: evidence of commitment to apoptosis rather than mitotic cell death. Clin Cancer Res 6: 3756-3765, 2000.

44. Duraj J, Zazrivcova K, Bodo J, Sulikova M and Sedlak J: Flavonoid quercetin, but not apigenin or luteolin, induced apoptosis in human myeloid leukemia cells and their resistant variants. Neoplasma 52: 273-279, 2005. 